\title{
The Bigger the Book: On Oversize Medieval Manuscripts
}

George Greenia

College of William and Mary, gxgree@wm.edu

Follow this and additional works at: https://scholarworks.wm.edu/aspubs

Part of the Medieval Studies Commons

\section{Recommended Citation}

Greenia, George, The Bigger the Book: On Oversize Medieval Manuscripts (2005). Revue Belge de Philologie et d'Histoire, 83(3), 723-745.

https://scholarworks.wm.edu/aspubs/591

This Article is brought to you for free and open access by the Arts and Sciences at W\&M ScholarWorks. It has been accepted for inclusion in Arts \& Sciences Articles by an authorized administrator of W\&M ScholarWorks. For more information, please contact scholarworks@wm.edu. 


\section{George D. GREENIA}

\section{The Bigger the Book: On Oversize Medieval Manuscripts}

A serious consideration of the archeology of the large format medieval book, including an examination of constraints on its production, its implied value as a totemic object, its original audience, and the intended performance of its texts in public settings, is an important area of research for cultural historians, but one which first must struggle against common representations of early books in popular Western culture. Modern movies that pretend to recreate a medieval setting routinely include oversize books among their most characteristic props. Besides being served up as the commonplace fixtures of monasteries and cathedrals, and evoking something of their same grand scale, big medieval style books are also movie trappings for an age not only untechnologized but desperately quaint and somewhat hopeless or ponderously mystical in its information retrieval systems $\left({ }^{1}\right)$. These unwieldy tomes are Hollywood's icons for an epoch of clumsiness, inefficiency and arcane knowledge. Real medieval books of monumental proportions do survive in considerable numbers although during the period that first created and used them their relative frequency must have been rather modest; smaller books were simply more common in the everyday life of medieval readers. But in our age handheld models are less appealing to movie audiences, and they tend to command less awe on the part of antiquarians and the bibliophiles they serve, at least as high visibility show pieces. Most modern, oversized coffee table books with their limited press runs and high prices emulate many of the showy characteristics prized in their forebears in the pre-modern book industry.

Exhibitions of medieval manuscripts, and the catalogues published to accompany those events, tend to celebrate large format books that may not be at all representative of the less showy majority of holdings of any major collection. Private collectors and those who cater to their tastes often veer toward objects of conspicuous consumption and display, which may actually correspond to some of the motives for a large book's original manufacture. One new title currently on sale, Modern Art: Revolution and Painting (Artmedia Press), retails for $\$ 6000$ and includes a handsome wooden stand to display the 75-pound leather-bound volume.

(1) To cite only a few examples of thousands possible, Monty Python and the Holy Grail includes a very funny scene of chanting monks punctuating their procession by banging their heads with heavy tomes, and in the movie version of Umberto Eco's The Name of the Rose, every book examined by William of Baskerville (Sean Connery) and novice Adso (Christian Slater) in their hasty perusal of the hidden library is a book of imposing proportions. The reliance on large books as visual icons pervades twentieth-century art, from the flopping stacks of chivalric novels in most nineteenth- and twentieth-century sketches of Don Quijote in his study, to art films, like Prospero's Books with its delirious library, or the erotic and calligraphic fantasy Pillow Book. 
Although measures of what counts as a "big book" are inevitably impressionistic, one could say that any tome that requires an adult reader two hands to handle, and that one would prefer to rest on some physical support like a table or book stand might count as an oversize volume for our purposes $\left({ }^{2}\right)$. This would include such celebrated medieval volumes as the Book of Kells $(33 \mathrm{x}$ $25 \mathrm{~cm})$, the Codex Calixtinus $(30 \times 22 \mathrm{~cm})$, the códice rico manuscript of the Cantigas de Santa Maria (49 x $33 \mathrm{~cm}$ ), MS 47-15 of the Cathedral of Toledo which starts with a copy of Alain of Lille's Planctus Naturae $(57 \times 41 \mathrm{~cm})$, the Libro del conocimiento de todos los reinos $(30 \times 21 \mathrm{~cm})$, or the Grandes Heures of Jean duc de Berry $(40 \times 30 \mathrm{~cm})$. The maximum size of a medieval folio is determined, of course, by the size of the animal skin it is made from, or the dimensions of the frame or mold that a papermaker's arms can span when casting leaves of handmade paper $\left({ }^{3}\right)$.

Turning points in the history of written culture are sometimes flagged for the historian by prominent works in a new format. One could recall the cultural and technical revolutions that marked the shift from roll to codex; the popularization of the portable one-volume bible in the early thirteenth century; the advent of printing and Gutenberg's 32-line Bible; the astonishing Polyglot Bible that Cardinal Cisneros created in Alcalá de Henares with fresh type fonts for Latin, Greek and Syriac; the dissemination of chapbooks among the lower classes in early modern England and Spain; and the creation of newspapers and the genres spawned by journalism $\left({ }^{4}\right)$. Printing took its lead from the manuscript culture that preceded and

(2) Francisco Mendoza Díaz-Maroto translates Eco's affirmation (in "Reflessioni sulla bibliofilia" : 2001) that "la forma-libro está determinado por nuestra anatomía. Algunos pueden ser muy grandes, pero suelen tener función de documento o decoración; el libro estándar no debe ser ni menor que un paquete de tabaco ni mayor que un periódico" (2002, p. 77).

(3) Walter Hart Blumenthal offers a playful glimpse of modern monstrous volumes devised as expansive gestures of respect, or stunts, like the Grosse Kurfürst Atlas (1666) of Frederick Wilhelm, the Great Elector of Brandenburg, which is nearly five feet, ten inches tall and clocks in at 275 pounds. Its size and sometimes fanciful manuscript maps made it a hit at the 1893 Chicago World's Fair. Accounts of these modern behemouths are spun as entertaining tall tales, but their creation and splashy celebrity are congruent with current thinking about large books as expressions of cultural capital.

(4) Although not an example of a change in book structure per se, these transition points include the manufacture of large-format vernacular manuscripts on paper in the late fifteenth century. Just as fashionable as books of hours, if less common, books on paper such as the hundreds of Spanish cancioneros (courtly songbooks) and the lavishly illustrated Paris manuscript of the Libro del caballero Zifar denote a cultural shift honoring secular tastes on a scale as grand as that reserved for theological tomes, a gesture that at very least borders on the presumptuous. The better known books of hours specially created for Jean duc de Berry are all on parchment and are still nominally religious, although secular representations predominate among the more distinctive - and unscripted - marginalia, and each volume dutifully functions as a usable prayer book. The duc de Berry collection of religiously themed books is legendary: his estate records show that he owned some 14 bibles, 16 psalters, 18 breviaries, 6 missals and no less than 15 books of hours, including the Très Riches Heures and his largest, the Grandes Heures. 
accompanied it for its first century of life, employing a full-size format for history, theology and law, half that for literary works, and finally half that again for the creation of the first true pocket-sized books beginning with Aldo Manuzio's edition of Ovid in 1501 (Mendoza Díaz-Maroto : 2002, p. 77). In the first half of the nineteenth century, the double elephantine sheets of the truly monumental Birds of North America prepared by John James Audubon (39 × 26 inches trimmed, or some $99 \times 66 \mathrm{~cm}$ ) are an extreme example, and one wonders how owners were expected to actually use these volumes or even turn the pages. Two major libraries in the United States, at the University of Pittsburgh and the Library of Congress, have decided to permanently disassemble their copies of Birds of North America to facilitate study $\left({ }^{5}\right)$.

But the concomitant issue to size is heft, and here the history of most medieval big books has been obscured. Some books, like Kells, used to exist as a single volume but have been redivided into multiple volumes to alleviate the deterioration caused by the weight of the components. In the case of Kells, the four sections that modern visitors admire also allow for public presentation of multiple page openings in their individual display cases $\left({ }^{6}\right)$. And of course, the bigger the book, the thicker the parchment needs to be, which also adds to the weight. As a tradeoff, it is more likely that larger books will trade the dense oak and maple commonly used for the cover boards of smaller books for lighter woods such as pine, so that the object does not become impossibly heavy $\left(^{7}\right)$. Even so, giant books that acquired cultural capital as display pieces were often propped up at an angle for casual viewers, especially in later historical periods, and their own great weight caused them to sag and pull free of their stitching and cover boards. Once their condition required rebinding, bigger books also became the victims of serial re-trimmings cruelly carried out to clean up tattered edges or shifted gatherings, and sometimes not without some measure of self-interest on the part of eighteenthand nineteenth-century commercial bookbinders. English apprentices were

(5) Audubon's Birds of America, published in Edinburgh and London from 1826-1838, contains 435 hand-painted prints whose ambitious size reflects the illustrator's determination to depict his subjects life size. There are only about 120 complete sets in existence and they were intended to be bound by their eventual owners into four volumes that would end up weighing some fifty to sixty pounds each.

(6) Again for reasons of conservation, the Great Domesday is now rebound in two volumes and the Little Domesday in three. The Codex Amiatinus with its 1029 folios is still in its original one-volume format and requires two men to transport it on a contraption that resembles a combination bookstand and divan.

(7) Broad spans of light woods like pine save on weight but create problems of their own: these cover boards may warp, and are too light to press their sheets flat, which allows the unruly parchment to swell and buckle all the more with changes in humidity, movement that can in turn tear the book block free of its sewing and covers. Subsequent rebinding often produces daft rearrangements of the contents, such as happened to the Book of Kells and the Très Riches Heures. Some large medieval books do have oak covers, like the Toledo volumes of the Bible moralisée (Lowden : 2000, 1, p. 100). 
allowed to appropriate the shop's parchment scraps to sell to tanners who added them to their boiling vats of hide glue, a practice that only encouraged those apprentices to trim old books more ruthlessly. Archeologists of the book must now undertake the laborious task of estimating original dimensions and weight for oversize medieval books by back calculating the size of untrimmed folios in something like their primitive binding.

As a very general rule, one could say that the bigger the book, the earlier its manufacture. Codices from the earlier Middle Ages include more large-format items, perhaps because the limited production of books precluded economies of scale that come with cranking out lots of smaller books. But just as likely, larger books survive from earlier periods because their imposing nature helped preserved them as objects of totemic value. Smaller books that were simple service copies were used until they were used up. When they became too worn, a fresh copy was made and the old copy discarded or recycled as a palimpsest or for paste downs. This practice might frustrate or sadden modern scholars and casual lovers of antiques, but we tend to forget that the nostalgic hoarding of relics from the past is a byproduct of Romanticism, or at farthest reach Renaissance raptures over a Classical past that was supposed to redeem and enlighten the present. Medieval scribes, on the whole a less impressionable tribe of craftsmen, appreciated the labor any finished book implied but could also cast a practical eye on even very old books as utilitarian objects that eventually needed to be retired and replaced.

As a diachronic sampling of book sizes sorted by century, consider the mean dimensions of books in the Beinecke Library at Yale, a distinguished and varied collection but one not put together to survey the history of medieval art nor to mount exhibitions of medieval artefacts for the general public.

\begin{tabular}{|c|c|}
\hline 8 th century & Beinecke MSS (all fragments with few folia) \\
\hline 9th century & $\begin{array}{l}\text { Beinecke MSS 206, 389, 401, 413, 442, Marston } 151 \\
\text { Mean: } 27.5 \text { x } 20.5 \mathrm{~cm} \quad \text { Mean surface area: } 564 \mathrm{~cm}^{2}\end{array}$ \\
\hline 10 th century & Beinecke MSS (all fragments with few folia) \\
\hline 11 th century & $\begin{array}{l}\text { Beinecke MSS 402, Marston 158, } 271 \\
\text { Mean: } 24.5 \text { x } 17.2 \mathrm{~cm} \quad \text { Mean surface area: } 421 \mathrm{~cm}^{2}\end{array}$ \\
\hline 12 th century & $\begin{array}{l}\text { Beinecke MSS } 126,154,181,189,191,210,280,282,315,330 \text {, } \\
336,393,403,414,450,471 \\
\text { Mean: } 27.9 \times 19.0 \mathrm{~cm} \quad \text { Mean surface area: } 530 \mathrm{~cm}^{2}\end{array}$ \\
\hline 13th century & $\begin{array}{l}\text { Beinecke MSS 26, 81, 82, 206, 207, 211, 214, 229, 322, 331, } \\
332,376,387,433,455,473 \\
\text { Mean: } 27.6 \times 18.5 \mathrm{~cm} \quad \text { Mean surface area: } 511 \mathrm{~cm}^{2}\end{array}$ \\
\hline 14th century & $\begin{array}{l}\text { Beinecke MSS } 6,13,18,33,60,80,83,102,157,220,227,339, \\
355,479 \\
\text { Mean: } 24.8 \times 17.4 \mathrm{~cm} \quad \text { Mean surface area: } 432 \mathrm{~cm}^{2}\end{array}$ \\
\hline
\end{tabular}



$101,106,107,110,138,223,462$ Mean: $19.1 \times 13.7 \mathrm{~cm} \quad$ Mean surface area: $262 \mathrm{~cm}^{2}$

These numbers are based on Barbara Shailor's three-volume Catalogue of the Beinecke with preference for manuscript books of prose works (excluding mere registers and account books) from western Europe that have not been assembled from gatherings of different sizes or periods. Despite a spike in the twelfth century, one recognizes a general trend toward smaller format. Admittedly, American library collections tend to be thin in very early books, well supplied with medieval bibles that are by and large more easily acquired and generously proportioned out of deference to their content and overstocked with late books of hours that are almost always of more modest size. These global figures do not attempt to correlate different ranges in overall folio size with other factors which may have influenced format, such as place of manufacture, monastic vs. noble patronage, number of folios, folio size vs. size of text block, parchment vs. paper, cropping and rebinding, sacred or secular purpose of book, presumed gender of maker or implied or intended user, genre of contents, classical vs. medieval time of composition of text transcribed, or Latin vs. vernacular texts $\left({ }^{8}\right)$. All these considerations would be important in developing a more comprehensive and nuanced survey of medieval codex format, while this essay is limited to implications of the upper ranges of overall book size.

Although specific needs, fashions and production styles flowed in diverse channels over the long span of the Middle Ages, some general directions can be pointed out in the tidal currents of books as indices of social practice. This may be especially true of larger book formats, where the bigger a book, the more it announces itself as a stage marker for conventionalized performances of authority, worship, wealth and class.

We can start by considering that, in general, the bigger the book the greater the initial investment (time, labor, materials) in its production. Big books obviously demand a lot more parchment, which means time to harvest the raw materials that go into them, and manhours of skilled craftsmanship in preparing the skins. Vellum production in particular cannot be rushed: a large format bible requiring 200 skins requires a patient culling of flocks as adult sheep and goats are taken in their mature years after yielding many profitable shearings, not to mention the material value of the offspring and milk of the ewes among them. The tradeoffs of age vs. ready availability of their hides are not just economic but a matter of quality as well. Adult animals yield parchment skins with larger writing surfaces, of course, but those skins come preinscribed with something of the life

(8) Nor do I try to bring into play Byzantine or Arabic manuscript production or use, and European Jewish books only to a limited extent. 
history of the creature making the donation. Life among brambles, clawing predators and the reproductive squabbles of the herd leaves its scars on sheep and goats, and so do shearings which generate nicks and scratches that turn into tough scar tissue. When it came time to clean and scrape the skin of an older animal to make it into parchment for an oversize book, all of those minors plugs of cicatricial tissue present rough spots of thicker dermis prone to tear away from the surrounding matrix of skin, opening up into stretch holes (ojos in Spanish codicology, yeux in French) so common in manuscripts of all sizes $\left({ }^{9}\right)$. Scarred skins have to be left thicker and cannot pared down for elegantly thin folia, and to some extent this extra strength is desirable in larger books which need heavier parchment so they don't tear from their own weight when the pages are turned, and so there is less visible bleed-through of writing from the opposite side of the page, a problem which may be exacerbated by the use of pigments with a deep bite or the broad, soaking strokes of a reed pen $\left({ }^{10}\right)$.

The bigger the book the more it becomes the object of a conspicuous dedication of resources and of conspicuous consumption. Even beyond the mysterious writing they contain, books exercise their maximum cultic function when they are large enough to be visible to a crowd. Religious examples come readily to mind, as when books are carried in procession as part of worship services. This sort of totemic deployment may also occur in secular settings when a patron commissions a book to serve as a powerful signal of his wealth, taste and devotion, or simply to create an heirloom object for his or her dynasty, such as happened with the Bibles moralisées for the generation of Louis IX in France (1120s and 1230s), and with large numbers of books of hours throughout northern Europe (fourteenth and fifteenth centuries).

An interesting case is the Libro del caballero Zifar which exists in two manuscript copies. The first, Madrid, Biblioteca Nacional MS 11309, transcribed in the fifteenth century, is an unillustrated codex perhaps prepared for the learned circle associated with the bishop's palace and court in Toledo where the book was probably conceived. Its 194 folios measure a redoubtable $29 \times 21.3 \mathrm{~cm}$. The

(9) "De forme arrondie ou elliptique, ces ouvertures dans la peau proviennent probablement de blessures endurées par l'animal, comme des piquares d'insecte ou des coups de corne, ou encore d'accidents survenus lors de la dépouille, comme la coutelure" (Lemaire: 1989, p. 19, Plate 10). Big manuscripts show holes because it is hard to avoid them in skins from mature animals unless one can afford to be very selective in picking from available stock. Small manuscripts display holes too, but sometimes because they are already conceived of as service rather than display copies.

(10) One can presume that most larger scripts were written with reeds rather than quills because even the largest birds with good primary flight feathers, geese and swans, produce quills of limited size. Moreover these quills have larger bore barrels that don't hold much ink because capillarity of adhesion does not function well within large cavities: the ink will just run out. Good reeds for copying manuscripts are mostly from southern, Mediterranean lands and therefore import items in northern medieval Europe. Therefore, the bigger the book the more routinely it was manufactured around the Mediterranean and / or the more laborious its production in northern climes because of a need to rely on import goods. 
second manuscript, Paris, Bibliothèque Nationale, Fonds Esp. 36, bears an astonishingly lavish 243 fully realized and large-format illuminations to help visualize the narrative, even through long stretches where the protagonist is repeatedly shown simply seated as he tells instructional tales to his attentive sons. There are also countless fantasy landscapes of castles and hillsides, noble warriors and stately ladies in all the latest fashions. It is complete in its original state without a folio missing or out of place. While the patron of this volume is unknown (it may have been the ill-favored Enrique IV, "El Impotente"), the book is anything but a study text. Its unscathed condition speaks of a dilettante's private collection of self-indulgences, something meant to impress peers and vassals but not a text with specific lessons to teach. The Paris Zifar generated no spinoff copies or print editions, inspired no literary continuations, bequeathed no legacy of imitators of its art.

The bigger the book the longer the "life span" of its implied readers. In the era before reading glasses were common, progressive myopia, also called presbyopia, would take the aging literate out of the pool of possible readers for texts written in normal size script, so that casual readers of slight public standing would have to rely on their personal memory hoard, which, as we now know from the work of Mary Carruthers, could be considerable. Readers of greater means or those more deeply embedded in a literate (university or religious or genteel) community could have texts read to them on demand or be able to count on listening to others reading them aloud. This correlation between the size of a book's script and the length of that book's usefulness to a given reader implies that books of fine script, which would normally be made in smaller formats as well, were destined for younger readers of good eyesight.

In the course of the medieval period book types diversified, most notably from the start of the High Middle Ages, when bibles in particular were sorted into volumes of like books of Scripture (bound manuscript copies of Prophets, Sapiential literature, histories, etc.), and then in the eleventh and twelfth centuries into large volumes for public or communal use $\left({ }^{11}\right)$. The miniature bible for personal use was rare indeed, although the odd copy, like Harvard MS Riant 20 with its diminutive $9.5 \times 5.5 \mathrm{~cm}$ pages (Light : 1988, pp. 21-23) may be found. The novel single-volume bibles that start to appear in the early thirteenth century - e.g., Beinecke MS 433 (Shailor : 1991, Catalogue \#79) - are clearly the handiwork and tools of the clear-eyed young students and preachers of the period, and perhaps served them as handy reference works when traveling in the company

(11) Laura Light's exhibition catalogue of manuscripts with copies of scriptural texts (bibles, liturgical books, commentaries and glossed copies) in the Houghton Library collection yields mean figures of $30.5 \times 20.3 \mathrm{~cm}$. with a mean surface area of $619 \mathrm{~cm}^{2}$. I only include eleventh- and twelfth-century codices and exclude fragments, books of mixed provenance / age, homilaries, and the anomalous Riant 20; measurements taken on catalogue \#4, 8-11, 15, 19-23, 26-27, 31-36 for a total of nineteen manuscripts. 
of older patrons who might request to hear passages from anywhere in Scripture. This implies that well-trained young readers with keen vision were part of a servant or service class, secretaries performing a somewhat menial function that at least put them in the presence of notables desiring their skilled labor. Books composed in elegant and minuscule script could be owned by anyone as luxury items, of course, but for the visually challenged to read for themselves, especially in moments of public and formal ceremony which corresponded to their rank, they would need bigger books with correspondingly amplified script $\left({ }^{12}\right)$.

The bigger the book the less portable that book is, and therefore the less influential among a wider community, synchronically and diachronically. A cathedral is executed on a vast scale but can be used and studied by thousands and is therefore highly influential even if perfectly immobile as a piece of architecture. But big books don't travel well either, and despite their eminence on site, even as a piece of cultural capital on display for major events and select visitors, the specific copies of the texts they contain are not that influential, in part because it is so inconvenient to use a huge exemplar as a source text to copy from. One might venture that for extremely well-known texts (Virgil, Gospels, etc.) where producing another reader's copy was not the point, the bigger the book the less assurance we should feel about the quality or accuracy of the copy transcribed. The Vienna Genesis is not an especially reliable copy of that sacred text, and the Vatican Virgil is full of mistakes, clearly a coffee table book for a wealthy patron. As far as we know, for all its fame the Book of Kells was never used as an exemplar to create another copy of its Gospels, which are full of scribal errors $\left({ }^{13}\right)$.

The monumental codices created at the behest of Alfonso X, el Sabio (12211284) in mid-thirteenth-century Spain are an even more telling example. Of the seventeen surviving manuscripts from the royal scriptorium, it was the more modestly proportioned books of legal codes and histories that unleashed a torrent of daughter copies, successors and adaptations, while the grand format books, like the four manuscripts of the Cantigas de Santa Maria, the Lapidario and the Libro

(12) Representations of scholars relying on eyeglasses only dates from the late Middle Ages and portraits set at public events still avoid the depiction of accessories that signal even mild disabilities like nearsightedness. In our own day there may still be something unseemly about using personal vision aids in public ceremonies.

(13) Although some have suggested that Kells's iconic value was so central to its purpose that it eclipses all other considerations, Carol Farr argues (against Jennifer O'Reilly who envisions contemplative readings of the book by individual monks, and Éamonn $\mathrm{O}^{\prime}$ Carragain who thinks that the book was rarely read at all) that a recreation of the liturgical context is central to understanding the physical book and its illustrations. See also Suzanne Lewis's review of Farr in Speculum. Farr notes that some graphic embellishments in Kells could have been useful visual prompts for readers even at distances of several meters $(1997$, p. 47). The accuracy of a text is not always impugned by its size. Barbara Shailor (1991, p. 75) notes that Beinecke MS 604, a "Lectern Bible from Paris", mid thirteenth century, "belongs to this tradition of lectern bibles; its large pages ( $15.5 \times 10.5$ inches) were probably designed to be read aloud. [...] Several of the folios bear the notation lectus et correctus, suggesting that there was considerable effort to insure the accuracy of the text". 
de los juegos, were near total cultural failures in that for all their splendor, and to judge from their sparkling condition, no one except the king seems to have ever used them. As far as we know, no copies of their texts were made in the Middle Ages and extant records of their existence are late and slight $\left({ }^{14}\right)$. Taken together, those six stunning manuscripts would have been sufficient to make the Alfonsine scriptorium famous in contemporary medieval studies, but had they been lost any time in the centuries following their creation we would never have known those books existed. Conversely, the smaller the book the more transportable it is, and the greater its potential for disseminating its contents although they may be less authoritative in this diminished format. And smaller books carry more chance of change of ownership, somcthing that gives them both greater anonymity (its provenance and "pedigree" does not travel with the book) and interchangeability of intellectual milieu (from monk, to young student, to retired nobleman, to his daughter, say).

The bigger the book, the less likely that there would be private additions in the form of personal notes, glosses, counter-arguments, etc. By contrast, in large format books that are equipped with glosses, those glosses and / or scholia may be as authoritative as the base text or the real point of the book in the first place. Many copies of the Glosa ordinaria show a handsome format separating biblical text from commentary, and many other works both earlier (like the ninth-century Greek texts of Ptolemy's Almagest) ${ }^{15}$ ) and later (like the fourteenth- and fifteenth-century copies of the Postilla of Nicholas of Lyra, or the stately Bolognese law books) $\left({ }^{16}\right)$ display this phenomenon, as do many medieval Jewish books $\left({ }^{17}\right)$.

The bigger the book the less likely there will be drolleries or capricious adornments. Larger format books are not necessarily outfitted with more illustrations, although some additional visual devices for guiding rcadcrs from text to text are common, as are presentation miniatures to announce the volume and its pedigree. The Codex Calixtinus, for example, has relatively few pages with miniatures, most notably the image of St. James that assumes the role of a presentation miniature on folio $1^{\mathrm{r}}$ and the double-page spread of decoration that occupies folios $162^{v}-163^{r}$ to mark the opening of the Historia Turpini. There are, however, illuminated capitals that span from 2 lines to 34, the entire height of the

(14) Queen Isabel I of Castilla is reported to have owned a copy of the Cantigas now lost (O'Callaghan : 1998, p. 8, n. 30).

(15) See Rome Reborn, Plate 111, and Plate 110 for a tenth-century copy of the same text, also with scholia in Greek.

(16) Representative manuscript copies: for Nicholas of Lyra, Beinecke Marston 215, 216 (sixteenth-century print copies of Nicholas of Lyra retain the same complex page layout and nearly the same dimensions); for Bolognese law text, Boniface VIII, Liber Sextus Decretalium, Beinecke, Marston MS 155 (Shailor : 1991, Catalogue \#31).

(17) Sirat shows how these classic dispositions of text and its accompanying scholia could be replicated in Jewish manuscripts and then print books over hundreds of years (1994, pp. 21 8-24). 
page. The Libro de los juegos is a lavish, oversized amusement, a picture book for an old man. Alfonso X had it completed in 1283 while bottled up in Seville where he would die in 1284. Its folios are proportioned for a prince and the illustrations overwhelm most pages, and are themselves gratuitous. The placement of chess, dice and backgammon pieces on their playing boards are useful enough, although they could have been rendered schematically and at a much smaller scale. Here they are inflated to almost life-size and every gambit of board play is turned into a full color vignette of some social group complete with hundreds of characters in stylish fashions from exotic Persian helmets to peek-a-boo déshabillé. But there are no drolleries or caprices in the margins, which among other things are signs of a second generations of readers and interpreters of a text, and of textual heirs who can stand apart from the received text and make signs about other discursive worlds and realities $\left({ }^{18}\right)$. Books of hours are the obvious examples of festive marginalia with their raucous visual horseplay; there must have been separate moments when owners prayed diligently while ignoring the racy marginalia, and other occasions when the book was passed around just for laughs. The smaller the book, the more marginalia or drolleries might be included if space were available for them in the margins. Larger books are less likely to have distinct settings for attending to disparate uses.

The bigger the book, the more readers could use it at one time. This is most obviously the case for choir books and other liturgical manuals (Graduals, Antiphonaries, etc.) which a group of singers could follow as they performed their musical parts in a liturgical service. It is also apparently true of Jewish services that might include songs performed by a trained choir (Metzger : 1982, Plate 365). This practice clearly enhances the sacred or at least social quality of the circumstances of use, and one could posit that the bigger the book the more the performance of its text was a communal one. One could evoke the shared songbooks of the Iberian cancioneros in Galician Portuguese (thirteenth century) or Castilian (fifteenth). Or the communal readings of heavily illustrated books, where a single reader provides the voice-over as it were for multiple viewers, such as with the Libro de los juegos (thirteenth century), the Anglo-Norman apocalypse books like the Cloisters Apocalypse (thirteenth to fourteenth centuries), or the Libro del caballero Zifar (late fifteenth century).

(18) This copy is a standout work of visual artistry and a lonely witness to excessive royal free time: no contemporary source notes its existence, there is no mention of it in the historical records for almost five hundred years, and no further copies of its original translations were ever made. The unique manuscript is completely intact as well, as if it never had another reader after Alfonso's death (except for some censorious prude who tried to hide the breasts visible under a woman chessplayer's gauzy shift by swabbing over the miniature). The legendary inhospitality of the Cathedral of Toledo where this manuscript was apparently stored helped preserve the Libro de los juegos - and thousands of other codices there - from the abusive attentions of later generations of readers. 
Conventions of communal use also imply that the bigger the book the greater the distance from its users when the book was put to its formal purpose, and therefore the more choreographed the actions that occurred around it: postures, movements, gestures made toward the book and toward others also in its presence; ritualized deployment of contents through recitation and chant; alternation of users; intervals of use; mode of storage, etc. Conversely, the smaller the book, the more intimate the distance between book and reader, and the more it suggests that the act of reading could inspire private contemplation, and that reflection on the text could take place in an environment of the reader's choosing and not necessarily in a church, school, or chapter house. These are the readers who, in the words of Walter Ong, "move out of the tribe" of their immediate oral circle and withdraw to a newly accessible inner space for reading.

The bigger the book the more scripted or marked the identity of the rightful user. A soloist for a specific chant sequence would, of course, have first rights to approach and use a large book on display as a centerpiece of a liturgical event. But so would a reader of a sacred text from a large format pericope or lectionary, or the officiating prelate at a solemn function who needed to proclaim his part as he blessed pilgrims, ordained new priests, consecrated an abbot or fellow bishop, or fulfilled any of the other rites contained in his missal, sacramentary, pontifical or rituale. The big book and the officiant are in a symbolic and symbiotic relationship where one echoes the power and authority of the other. Medieval Jewish liturgical practices show convergent ritualized gestures with rabbis and lay readers carrying oversize Torah scrolls in their synagogues (Metzger : 1982, Plates 92, 97, 99, 197).

Books record language acts in frozen linearity, a transcription of natural speech in a formalized sequence. Of course, written records are never adequate in any writing system for expressing the nuances of living language despite elaborate graphic devices meant to encode shifts in dramatic performance and even breathing: most punctuation marks in medieval manuscripts are principally stage directions for a living performer (Parkes : 1993). But writing systems permit a solitary reader to free the language he or she surveys from its lockstep march forward by skipping ahead, rereading passages, slowing down to add mental echo and weight to a section, and skimming at a faster rate to complete a thought already grasped. The smaller and more "holdable" the book, the more recursive the reader's interaction with the content: the more it becomes "flippable" so complementary notions can be consulted and compared anywhere within the covers, and notions of what counts as complementary can be created by the individual reader on the spot. And the smaller the book, naturally, the more common a sotto voce reading of it. But the bigger the book, the more a single oral reader controls these interpretive possibilities for all those present, and exercises his or her claim to leadership, performing as the mind which processes the text in a theatrical way for all those participating in the living cognitive drama. 
This is as true in the classroom as it is in the chancel of a cathedral. Teachers are routinely equipped with bigger books, annotated teachers editions, whose thicker physical presence underscores their users' authority, provides them with at least some additional knowledge, and helpful prompts for the actualization of the lessons, showing how to frame them gesturally as the scholia and glosses in a medieval manuscript frame the honored text at the center. Manuscript 47-15 of the Cathedral of Toledo, a book as broad as a small door, is immobilized by its own weight, and monumentalized by the requirement to use it on a table top where appropriate authorities can be arrayed around it to enact their social roles of teachers and learners (Greenia : 1989). Expansive social place holders like oversize books require us to try on some level to imaginatively recreate the cloud of discourse and debate that hovered in the air just beyond their visible margins and which left only the occasional written residue on them.

One might say that the bigger the book, the greater its presumed authority and the implied durability of that authority. That is why bibles are routinely the largest books in Christendom, Torahs among Jewish communities, and Korans in Muslim lands. In the realm of education, depictions of medieval masters gripping their larger books at the head of their study halls are common, and the same sort of imagery also occurs in representations of Jewish sages using their books to lead rabbinic disquisitions (Metzger : 1982, Plates 175, 185, 217), to instruct youths (Plates 176, 260), or even to perform bibliomancy (Plate 291) $\left(^{19}\right.$ ).

Authority and its negotiated relationships may be the entire point of a book in the first place. The staggering Codex Amiatinus (50 x $34 \mathrm{~cm}$., 1029 folios) was created in far-off England around 715 as a demonstration of the erudition and orthodoxy of the English hierarchical establishment. This copy of the Gospels was a faithful transcription of one probably created by Cassiodorus at his monastery at Vivarium in southern Italy, and therefore a testimony to the continuity of scriptural authority shared as far away as the North Sea, an authority emblazoned in the image on folio 1 of a scholar (originally Cassiodorus himself, the representation being reassigned in the Amiatinus to the prophet Ezra) with his sacred writ stacked

(19) Thérèse and Mendel Metzger offer a useful definition of the practice of bibliomancy by learned Jews: "...the interpretation of a word or verse that first attracts their eyes as an omen when opening at random the volume of the Bible". Thomas Aquinas specifically condemned the practice as superstitious and an attempt to force God into revealing a hidden truth. The most commonly represented Hebrew books after the iconic Torah scrolls, which stand for both God's law and man's worship of it, are haggadot or books containing the texts for the celebration of the Seder meal in a Jewish home at Passover (Plates 150, 378). These dinner table books are always modestly scaled and meant for domestic rather than public use, or to look at it another way, the most telling lessons and the central ritual for Jewish life were assigned to home schooling rather than communicated through formal services held in public spaces dedicated to prayer. And some copies, like the celebrated Darmstadt Haggadah from Eastern Europe, show as many women as men using haggadot and other books, while the Sarajevo Haggadah from Spain depicts small boys at the local synagogue holding Seder service books in their hands as if they were heading home with their primers (Metzger : 1982, Plates 88, 103). 
in a bookcase behind him. The codex set out accompanying retiring Monkwearmouth / Jarrow abbot Ceolfrith to Rome to serve as a career-capping gift to the Pope; sadly, Ceolfrith died en route and the book was all too gladly sheltered for long years at the monastery of Monte Amiato, which eventually, and just as gladly, lent its name to the tome. And tried to steal its authority. In a now famous act of identity theft, the monks at Amiato carefully scrapped off Ceolfrith's name from the dedicatory inscription and replaced it with that of a local saint. So the importance of the Codex Amiatinus as a token of authority and the rightful transmission of that magisterium imposed itself on the volume from its conception to its ultimate site of repose.

Sccular power brokers relied on the same mechanisms to codify their authority in codices. The elaborate and oversize Toledo Bible moralisée $\left({ }^{20}\right)$ may have entered Spain as a dynastic exchange gift in 1269 when Blanche, the daughter of Louis IX, married Fernando de la Cerda, the firstborn son and heir to the throne of Alfonso X (Greenia : 1997; Lowden : 2000, 1, pp. 132-34). Louis and his mother, another Blanche, had portraits of themselves painted into the unique capstone miniature that closes the final volume, and it is precisely this patron folio that was detached from the book perhaps as early as the eclipse of Alfonso's own reign when the same French family backed the offspring of their dynastic union against Alfonso's ultimately victorious second-born son, Sancho IV, el Bravo. Alfonso for his part may have been carrying one or more of the fabulous copies of the Cantigas de Santa Maria with him to Beaucaire to present to the Pope at their strategic parley in 1275 (O'Callaghan : 1998, p. 134).

The bigger the book the more bound it was to a single user group and probably the more likely it was made for a specific circle of readers in the first place. Besides the obvious implications for religious and educational settings, one might recall the geographic stability of reference tools like the law codes that needed to be kept on hand at administrative centers like Rome, Bologna, London and Paris $\left({ }^{21}\right)$. Medieval book hoards are the natural byproduct of any established administrative center, but also a favorable inducement for picking a site. Seats of power like Rome, Paris and London functioned as breeder reactors for books and encouraged the complementary growth of education, theology and law and the voluminous works that served each singly or all at the same time. Bigger books with all their gravitas helped anchor such centers against the tides of competing

(20) Current trimmed dimensions of the Toledo volumes are $41.3 \times 30 \mathrm{~cm}$., but based on this copy's unaltered cover boards, reused in its last rebinding, and the contemporaneous and still uncropped Bible moralisée in Vienna (MS 1179), Lowden calculates original measurements of $43 x$ $31 \mathrm{~cm}$. (1, p. 101) including for the detached quire now known as Morgan MS $240(1$, p. 136)

(21) The weighty Domesday volumes are something of an exception as their peripatetic career attests: they were frequently on the move as a sign of the king's presence and near omniscience within his realm, but their normal residences were found in London and in Winchester in the Royal Treasury. 
upstart groups who, understandably perhaps, sought to burn the libraries and record houses of the establishment as part of any attempted coup.

Medieval Castile presents interesting circumstances since its emergent monarchy had no permanent home or seat of power. The royal archives traveled with the king as he made the rounds of his unstable feudal territories and even the war-torn military frontier in the south. Deals struck and concessions granted during royal visitations were often couched in provisional terms pending the arrival of the baggage train, and confirmation of freedom from conflict with previous pacts with towns and noble petitioners. Local scribes and notaries were drafted into the service of the royal scriptorium at each stop along the way and these part-timers routinely kept certified copies of the documents they produced as part of the local registry. As a consequence, much of the documentary evidence for Castile's regal dealings from the thirteenth to the fifteenth centuries is now scattered among municipal and private archives; seeding these multiple copies throughout the realm offered a measure of security denied to the itinerant secretaries of the king.

All the more reason to marvel at the early initiatives of Alfonso X. His father, Fernando III (1199-1252), was thirteen when the united kingdoms of Spain won their decisive victory over the massed Moorish hosts at Las Navas de Tolosa, and Fernando dedicated most of his energetic rule to pressing the Reconquest further south, in his final years with his eldest son Alfonso serving as field marshal at his side. Although bred as a warrior, this prince and later king displayed unusual devotion to letters, having Arabic and Latin works translated and ordering - and personally editing - massive historical and legal compilations of all available prior work in those fields. King Alfonso put into practice what his father had expectantly decreed, that Castilian would be the official written language of his lands for all transactions. He traveled incessantly during his reign, forced to rely on the same traditional wandering legal archives used by kings before and after him, but also deftly setting up an efficient royal scriptorium in each locale where he took up residence. These were not mere legal offices with appropriate secretarial pools. Alfonso also sustained scholarly teams of translators and legislative consultants, many foreign, who worked steadily at creating the grand histories and law codes that would help forge the Spanish national imaginary $\left({ }^{22}\right)$.

One is struck by the princely dimensions ordered up by this monarch for his personal library of commissioned works. The commanding proportions of his royal copies of the Cantigas de Santa Maria should have kept them parked at

(22) This essay is only concerned with the structures and user communities of imposingly proportioned codices, but one could consider comparable issues for legal instruments on single sheets which could be unfurled like imperial standards at public gatherings to impress an assembly of many viewers, fewer listeners and still fewer actual readers. The royal proclamation of exile cited twice in the Spanish Cantar de mio Cid (lines 24 sand 43) and the showy Spanish previlegios rodados of the thirteenth century onward come to mind. 
some sheltering institution for long stretches, but some at least traveled with the king as devotional objects. In 1276, after a rendezvous with Pope Gregory $\mathrm{X}$ at Beaucaire in southern France and a failed attempt to convince him to recognize Alfonso as Holy Roman Emperor, and after suffering multiple personal and political disasters at home both during his absence and on his return, the Spanish monarch fell seriously ill in Vitoria. The lyrics of Cantiga 209 recount this episode, and how Alfonso commanded the book of the Cantigas be brought to him as he lay prostrate $\left({ }^{23}\right)$ in bed. The physical imposition of this tome, a weighty token of Alfonso's lifelong piety and the craft of his court poets, miraculously restores his health, and a later second volume of the same anthology in its illuminations (Florence manuscript, f. 95) depicts the autobiographical event of Alfonso being cured by the arrival of an oversize book which is laid open on his body.

The bigger the book, the harder it is to close. This truism could be taken as mere slapstick, that vastly oversize books require comic gestures to tote them around or handle them, a set of stage business common enough in representations of modern medievalism in that really large volumes turn into props for actors performing all sorts of entertaining physical routines on stage and screen. And I suggested earlier in this essay that massive books are harder to close in the sense that the performance of their texts requires a consensus on when the collaborative drama, the improvisational readers theater that is the core sociological event within a circle of literate minds, is over $\left({ }^{24}\right)$.

There is also a larger sense about the book being closed or open, this time from modern critical notions of closed and open texts. Closed texts tend to present finite truths, raise issues with single answers, and do not invite interpretation or glossing. Meaning is stable, reliable, static. Books of science, instructional and maintenance manuals for machines, diet guides, how-to books and office memos are all self-proclaimed closed texts, and their interpretation or unpacking is circumscribed by fairly tight social and institutional conventions. Open texts are, in a now classic, almost moral sense, those that welcome and indeed insist on

(23) O'Callaghan recounts the complete historical events (2000, pp. 141-43). Walter Mettman takes this to refer to the early compilation of one hundred cantigas now identified as the Toledo manuscript which measures $31.5 \times 21.7 \mathrm{~cm}$.

(24) Belonging to a literate oral community does not require the ability to read. Frequent exposure to texts read aloud for the shared reflection and comment of a circle of thinkers is enough to allow one full participatory rights and even leadership within such a group. One dramatic example in Eco's The Name of the Rose is the blind character Jorge of Burgos, the most influential, indeed terrifying, commentator of scripture within his monastic community. Participation in literate oral communities only some of whose members actually share duties for reciting the written texts in play must have been common among medieval religious women. In recent times, Vincent Barletta has done field work as a linguistic anthropologist among Franciscan comunidades de base in Chiapas, México where among the local lay Third Order Franciscans some of the conveners and most respected textual commentators are themselves incapable of reading the written word. 
freighting multiple meanings, texts that fully intend to provoke readers by their artfully embedded ambiguities and tensions. Umberto Eco has called novels engines for generating interpretations, and the more successful the novel, the more readings it spawns among those who ponder and sometimes claim to arbitrate its implicit truths. Meaning is fluid, evolving, multifaceted and renewable in each successive individual reading and for each community of readers $\left({ }^{25}\right)$.

Oversized manuscript books straddle the categories of open and closed in purposeful ways. They are closed texts in that their contents may be regarded within a given community as stable. Nuns chanting psalms from their choir books take for granted that their performed readings, and the spiritual import they give to them, are convergent among all true Christians and reliably orthodox. Medieval readers of Aristotle too may have agreed to tacitly accept that Aristotle was trying to say something stable and true, if highly complex and implying consequences or extensions difficult to enumerate and exhaust. The faithful who celebrate the feast of a martyr or the dedication of a church by performing sacred scripture from a massive lectionary declare by their ritual that the text is closed in that this is the right way to reflect on the event they are commemorating, and the description of the new Jerusalem they recite from the Book of Revelation is about the nature of the Church as reflected in its sacred architecture. As performed for the annual commemoration of the dedication of a church, that text is not about, say, the mystical properties of the gem stones that comprise its building blocks and columns or about the social constructs of redeemed communities, although medieval and modern theologians may embrace those readings as more pertinent in other, more open occasions for performing the same sacred script.

But big books in the hands of medieval readers are just as often copies of open texts which welcomed collaborative work to reassemble their truths in the open air and quite literally in the middle of the room. They are hard to close because their meanings are dodgy, and the task of negotiating their interpretation is the proper exercise of reason itself. Doggedly keeping texts open is the process which trains readers in textual hermeneutics, and for medieval readers, in holy wisdom. Small books by contrast are often easier to "close". As privatized copies of texts, they are less often asked to deliver their sense to an interactive public scrutinizing interpretative options. The smaller the book, the more solo users can convince themselves that its contents are othodox.

And finally, the bigger the book, the more teasing the implications for the historian of written culture. To cite just one area that requires further reflection, there is the matter of book size / weight and gender. Communities of religious

(25) Carol Farr (1997, pp. 46-48) insists on the openness of the Book of Kells, a point she notes is echoed by Jonathan Alexander and Umberto Eco (both in Peter Fox's facsimile edition : 1990), and John Higgitt and Jennifer O'Reilly. The modern critical preference for the open-endedness of texts and the books that contain them has become something of a cliché and prerequisite for a work's inclusion in the medieval canon and a cause for the expansion and blurring of canons in general. 
women certainly used oversize choir books by themselves on a routine basis, and since many of their liturgical celebrations were Propers for the saints of their Order or their individual monastic house, there is good reason to think that they made those books themselves or at least collaborated in their creation. Their books for the celebration of Mass and the sacraments may have been handled mostly by men during those rites, but the women kept the books in their sacristies and libraries, and the illustrations were often unmistakably designed for their contemplation, such as those in the Uta Codex so ably studied by Adam Cohen, a book of 119 stately folios and of considerable weight. The Anglo-Norman Apocalypses such as the Cloisters Apocalypse are said to have been created for the reflection of noble lay women, and in some ways - fewer folios, lighter weight, brief texts in fairly easy Latin - they seem well suited for domestic consumption $\left({ }^{26}\right)$. Books of hours (which harken back to at least 1240 and the De Brailes Hours, created for an unknown laywoman named Suzanna) multiplied with dizzying speed in the fifteenth century and were not only household tools to promote literacy but something of a fashion accessory for aristocratic dames lingering at the doorways of their churches. Many of these handsomely decorated prayer books are in pristine condition, which means they were little prayed from, but far more modest and prayer-worn books of hours survive in great numbers, books which clearly gave years of hard service to the truly devout, male and especially female. The diminutive size of these devotional works for the laity corresponds to their owners requirements for portability and also intimates an increasingly privatized experience of religion and the shrinking scale of the public, cultic function of the practice of their faith $\left({ }^{27}\right)$.

The age of the monumental manuscript book is happily not over yet. St. John's Abbey in Collegeville, Minnesota, and its Hill Monastic Manuscript Library commissioned Donald Jackson, England's and arguably the world's most distinguished calligrapher, to create the St. John's Bible, the first completely hand-copied and illuminated bible since the Middle Ages, and the dimensions are suitably monumental. At completion, its seven volumes will include a thousand parchment folios, hundreds of miniatures and countless historiated capitals and other line decorations. The first volumes finished span 23 by 15.75 inches $(58.4 \mathrm{x}$ $40 \mathrm{~cm}$ ) and once bound will weigh in at something close to a daunting fifty pounds

(26) The celebrated Beatus series of Apocalypse manuscripts, also handsomely oversized, were exclusively monastic productions.

(27) The articles and illustrations in (Taylor and Smith : 1996) offer insights on medieval representations of women and the books that filled their public and private spaces, including a number of larger format books, although in some instances the size of the book shown may be a byproduct of the need to depict clearly visible icons as place holders in a key scene of piety (the prayer book nudgingly represents itself as filling a lady's hands and fully occupying her mind), and to represent hierarchies of scale (bigger books for more important people). So the real books that medieval women actually used may not have been all that big, but their dominance in the miniatures confirm why big books were preferred in certain real-life settings. 
each. But the importance of this three-million dollar project embraces more than an act of nostalgia, piety or creative anachronism. Commissioned as the "First Bible of the Twenty-first Century", the Benedictine Abbey of St. John undertook this project partly from true devotion, partly to attract new donors to this and related ventures, and also as a publicity generator for their educational and religious missions. It quickly morphed into a project that helped deepen the focus of the monk's monastic, university and extended communities and became a tangible method of concretizing their identity in the face of the benign tolerance monks usually inspire among the secular public.

A team of scriptural and artistic consultants was assembled from among the monastic community and professors in the St. John's School of Theology in Minnesota, which faxed vision statements, directives and brainstorming to Wales where Jackson set up a scriptorium for his team of calligraphers and illuminators. The creative ferment of these complementary teams generated some happy surprises and some occasional stumbles as are likely with any big project. The lead artist was forced to recast some of the proffered theological niceties in more practical terms and images. He executed one elaborate symbolic illumination for the wrong biblical figure, losing a whole folio in the process, but had a little mildly naughty fun of his own when the lace from the hem of his daughter's nighty was dipped in pigment to lay down a decorative border on several pages of sacred script.

The premiere of the first volume delivered to the monastic community at St. John's looked like a cross between the opening of a major movie and a papal visitation. The press stood in respectful rows with their cameras and microphones poised for live coverage of the ceremonies, spotlights were arrayed to ignite the gold in the illuminations visible in the book when opened on the lectern, prefilmed background interviews with the abbot and the teams of consulting theologians stood ready to splice into empty moments, and a special Scripture service created by the monks started with a formal procession into the abbey precincts and reached its zenith with majestic readings from the St. John's Bible, all as a set piece of paraliturgical theater.

The creation of the St. John's Bible serves as a useful demonstration for many of the hypotheses enumerated in this paper - about the collaboration between a cultivated communal imagination and the artisans who are tasked to express it, the conception and execution of an expensive institutional emblem, the authority implicit in the inauguration and use of a cultic symbol, the choreography of its ritualized deployment, and its value as cultural capital. The history of the grandly scaled medieval book demands consideration of these and comparable issues, for often the bigger the book, the bigger its implications for the inner workings of literate societies. 


\section{Works Cited}

ALEXANDER (Jonathan), "The Illumination", in (Fox : 1990), pp. 265-303.

BLUMENTHAL (Walter Hart), "Goliaths of Bookdom", in Bookmen's Bedlam. An Olio of Literary Oddities (New Brunswick, NJ : Rutgers University Press, 1955), pp. 94-105.

CARRUTHERS (Mary), The Book of Memory: a Study of Memory in Medieval Culture (Cambridge [England]-New York : Cambridge University Press, 1990).

CARRUTHERS (Mary) and ZIOLKOWSKI (Jan M.), eds. The Medieval Craft of Memory: an Anthology of Texts and Pictures (Philadelphia : University of Pennsylvania Press, 2002).

COHEN (Adam S.), The Uta Codex. Art, Philosophy, and Reform in EleventhCentury Germany (University Park, PA : Penn State Press, 2000).

ECO (Umberto), "Reflessioni sulla bibliofilia", L'Esopo. Rivista trimestrale di Bibliofilia, 85-86 (marzo-giugno 2001), pp. 23-38.

FARR (Carol), The Book of Kells. Its Function and Audience (London-Toronto : The British Library-University Press of Toronto Press, 1997).

Fox (Peter), ed. The Book of Kells: MS 58 Trinity College Library Dublin (Luzern ?, 1990).

GRAFTON (Anthony), ed. Rome Reborn. The Vatican Library and Renaissance Culture (Washington : Library of Congress, 1993).

GreENIA (George D.), "A New Manuscript Illuminated in the Alphonsine Scriptorium", Bulletin of the Cantigueiros de Santa Maria, 2 (Spring 1989), pp. 31-42.

GREENIA (George D.), "University Book Production and Courtly Patronage in Thirteenth-century France and Spain", in KAGAY (Donald J.) and SNOW (Joseph T.), eds. Medieval Iberia: Essays on the Literature and History of Medieval Spain (New York : Peter Lang, 1997), pp. 103-128.

LEMAIRE (Jacques), Introduction à la Codicologie (Louvain-La-Neuve : Université Catholique de Louvain, 1989).

LEWIS (Suzanne), "Review of Carol Farr, The Book of Kells", Speculum, 77 (2002) 2, pp. 519-21.

LIGHT (Laura), The Bible in the Twelfth Century. An Exhibition of Manuscripts at The Houghton Library (Cambridge, MA : Harvard College, 1988).

LOWDEN (John), The Making of the Bibles Moralisées, I, The Manuscripts (University Park, PA : Penn State Press, 2000).

LOWRY (Glenn D.) with NEMAZEE (Susan), A Jeweler's Eye. Islamic Arts of the Book from the Vever Collection (Washington: Smithsonian Institution, Arthur M. Sackler Gallery, 1988).

MENDOZA Díaz-MAROTO (Francisco), La pasión por los libros. Un acercamiento a la bibliofilia (Madrid : Espasa, 2002). 
METZGER (Thérèse and Mendel), Jewish Life in the Middle Ages (Seacaucus, NJFribourg [Switzerland] : Chartwell Books-Office du Livre, 1982).

O'Callaghan (Joseph F.), Alfonso $X$ and the Cantigas de Santa Maria. A Poetic Biography (Leiden : Brill, 1998).

PARKES (Malcolm), Pause and Effect: An Introduction to the History of Punctuation in the West (Berkeley : University of California Press, 1993).

SHAILOR (Barbara A.), Catalogue of Medieval and Renaissance Manuscripts in the Beinecke Rare Book and Manuscript Library Yale University, I, MSS 1-250, II, MSS 251-500 and III, Marston Manuscripts (Binghamton, NY : Center for Medieval \& Early Renaissance Studies-SUNY-Binghamton, "Medieval \& Renaissance Texts and Studies 34, 48 and 100", 1984, 1987 and 1992).

SHAILOR (Barbara A.), The Medieval Book. Illustrated from the Beinecke Rare Book and Manuscript Library (Toronto : University of Toronto Press, 1991).

Sirat (Colette), Du Scribe au Livre. Les Manuscrits Hébreux au Moyen Âge (Paris : CNRS Éditions, 1994).

TAYLOR (Jane H.M.) and SMITH (Lesley), Women and the Book. Assessing the Visual Evidence (London-Toronto : The British Library-University Press of Toronto Press, 1996).

Tesoros de España. Ten Centuries of Spanish Books (New York-Madrid : New York Public Library-Ministerio de Cultura, 1985).

\section{Manuscripts and Other Big Books}

AlaIN OF LILle, Planctus Naturae and diverse treatises by ARISTOTLE, Cathedral of Toledo MS 47-15. Late thirteenth century. 57 x $41 \mathrm{~cm}$.

Alfonso X, el Sabio, Cantigas de Santa María (Códice rico), Escorial Monastery Library MS T.I.1. Third quarter of thirteenth century. $48.5 \times 32.6 \mathrm{~cm}$.

Alfonso X, el Sabio, Cantigas de Santa Maria, Florence, Banco Rari 20. Third quarter of thirteenth century. $45.6 \times 32.0 \mathrm{~cm}$. [companion volume to the Códice rico].

Alfonso X, el Sabio, Cantigas de Santa María (Códice de los músicos), Escorial Monastery Library MS J.b.2. Third quarter of thirteenth century. $40.2 \mathrm{x}$ $27.4 \mathrm{~cm}$.

Alfonso X, el Sabio, Cantigas de Santa María (Códice de Toledo), Madrid, Biblioteca Nacional 10.069. Third quarter of thirteenth century. $31.5 \mathrm{x}$ $21.7 \mathrm{~cm}$.

Alfonso X, el Sabio, Lapidario, Escorial Monastery Library MS h-I.15-16. Ca. $1250.40 .2 \times 29.1 \mathrm{~cm}$.

Alfonso X, el Sabio, Libro de los juegos (Libros de ajedrez, dados y tablas), Escorial Monastery Library MS T.I.6. 1283.40 x $28 \mathrm{~cm}$. 
Astronomical-Mathematical Collection. Vatican Library, Vat. gr. 204. Tenth century. [Rome Reborn, Plate 110] 34.5 x $25.1 \mathrm{~cm}$.

AuduBon (John James), Birds of America, Edinburgh and London from 18261838. [published as unbound plates] $99 \times 66 \mathrm{~cm}$.

BeAtus of LIÉBANA, Commentaries on Apocalypse (= Beatus of Fernando and Sancha), Madrid, Biblioteca Nacional MS Vit. 14-2 (olim B.31). 1047. 36 x $28 \mathrm{~cm}$.

Beatus of Liébana, Commentaries on Apocalypse, Burgo de Osma, Catedral Cod. $1.1086 .36 \times 25.5 \mathrm{~cm}$.

Beatus of LIÉBANA, Commentaries on Apocalypse, Escorial Monastery Library MS \&.II.5. Tenth-Eleventh centuries. $33.5 \times 22.5 \mathrm{~cm}$.

Beatus of LiÉBana, Commentaries on Apocalypse, Gerona, Catedral, MS 7. 975. $40 \times 26 \mathrm{~cm}$.

Beatus of liébana, Commentaries on Apocalypse, Madrid, Academia de la Historia, Cod. Aemilianensis 33. Late Eleventh century. $35.5 \times 24 \mathrm{~cm}$.

Beatus of LiÉBANA, Commentaries on Apocalypse, Archivo Histórico Nacional Cod. 1097B. $968.36 \times 25.5 \mathrm{~cm}$.

Beatus of LiÉBana, Commentaries on Apocalypse, New York, Pierpont Morgan Library MS 429. $1220.52 \times 36.4 \mathrm{~cm}$.

Beatus of LiÉBana, Commentaries on Apocalypse, New York, Pierpont Morgan Library MS 644. Tenth century. $38 \times 28 \mathrm{~cm}$.

Beatus of Liébana, Commentaries on Apocalypse, Seo de Urgel, Catedral. Tenth century.] $40 \times 27 \mathrm{~cm}$.

The Beaupré Antiphonary, Baltimore, The Walters Art Gallery, MSS W.759-762 (4 vols.). 1290. Vol. 1, $49 \times 34.5 \mathrm{~cm}$; Vol. 2, $49 \times 32.5 \mathrm{~cm}$; Vol. 3, 42.5 x $31.3 \mathrm{~cm}$; Vol. $4,49 \times 34.5 \mathrm{~cm}$.

BERRY (Jean, duc de), Grandes Heures, Paris, Bibliothèque Nationale, lat. 919. $1409.40 \times 30 \mathrm{~cm}$.

Berry (Jean, duc de), Petites Heures, Paris, Bibliothèque Nationale, lat. 18014. ca. $1410.19 \times 11 \mathrm{~cm}$.

Berry (Jean, duc de), Belles Heures $(=$ Ailly Hours), New York, Cloisters MS $54.1 .1 .1408-1410.23 .8 \times 17 \mathrm{~cm}$.

BERry (Jean, duc de), Très Riches Heures, Chantilly, Musée de Condé MS 65 (olim 1284). 1411-1416 (illuminations completed 1485-1490). $29 \times 21 \mathrm{~cm}$.

Bible, New Haven, Yale University, Beinecke Library, MS 604. Middle of thirteenth century. [Shailor, The Medieval Book, Catalogue \#78] $39.4 \mathrm{x}$ $26.7 \mathrm{~cm}$.

Bible moralisée, Toledo, Biblioteca del Cabildo [de la Catedral], MSS 1-2. 3 vols. $1225-1235.41 .3 \times 30 \mathrm{~cm}$.

Bible moralisée, New York, Pierpont Morgan M. 240 [one quire detached from end of Toledo, Vol 3]. 1225-1235. $37.8 \times 26.1 \mathrm{~cm}$. 
Bible moralisée, Vienna, Österreische Nationalbibliothek, MS 1179. 1220s. 43 $\times 29.5 \mathrm{~cm}$.

BONIFACE VIII, Liber Sextus Decretalium, New Haven, Yale University, Beinecke Library, Marston MS 155. Ca. 1325. [Shailor, The Medieval Book, Catalogue \#31] $45 \times 27.5 \mathrm{~cm}$.

Book of Durrow, Dublin, Trinity College, MS 57 (olim A.4.5). Late Seventh century. $24.7 \times 22.8 \mathrm{~cm}$.

Book of Kells, Dublin, Trinity College MS 58 (olim A.1.6). Eighth century. 33 x $25 \mathrm{~cm}$.

Book of Lindisfarne, London, British Library MS Cotton Nero D.iv. Mid-tenth century. $34 \times 24 \mathrm{~cm}$.

The Cloisters Apocalypse, New York, The Cloisters. Early fourteenth century. 30 $\mathrm{x} 22.5 \mathrm{~cm}$.

Codex Amiatinus, Florence, Biblioteca Medicea Laurenziana Amiatino 1. Before $715.50 \times 34 \mathrm{~cm}$.

Codex Aureus of St. Emmeram (Golden Gospels of Charles the Bald= Liuthart Gospels), Münich, Bayerische Staatsbibliothek Clm. 14000. 870. 42 x $33 \mathrm{~cm}$.

Codex Aureus Scorialensis (= Golden Gospel Book of Henry III), Monasterio de San Lorenzo de El Escorial, Vitr. 17. 1033-1039. $50.7 \times 33.5 \mathrm{~cm}$.

Codex Calixtinus, Santiago de Compostela. 1130-1140.. $30 \times 22 \mathrm{~cm}$.

Great Domesday, London, Public Record Office. 2 vols. $1086.38 \times 28 \mathrm{~cm}$.

Little Domesday, London, Public Record Office. 3 vols. 1086. 28 x $20 \mathrm{~cm}$.

The First Bible of Charles the Bald, Paris, Bibliothèque Nationale, lat. 1. 846. 49.5 $\mathrm{x} 34.5 \mathrm{~cm}$.

Hebrew Bible, Madrid, Biblioteca de Palacio MS II-3231, 1487. [Tesoros de España Catalogue \#4] $10.5 \times 9 \mathrm{~cm}$.

Hebrew Bible, Madrid, Biblioteca Nacional MS Vit. 26-6, Fourteenth-fifteenth centuries. [Tesoros de España Catalogue \#3] $31 \times 23 \mathrm{~cm}$.

Koran, Madrid, Biblioteca de Palacio MS II-3228, 1720. [Tesoros de España Catalogue \#6] $5.9 \times 5.9 \mathrm{~cm}$.

Koran, Washington, The Sackler Gallery, MS. S86.0066. 14th century. [Lowry, Plate 1] $41.6 \times 31.6 \mathrm{~cm}$.

Koran, Washington, The Sackler Gallery, MS. S86.0082, S86.0083. Iran, ca. 1550. [Lowry, Plate 2] $42.4 \times 26.9 \mathrm{~cm}$.

Libro del conocimiento de todos los reinos, Münich, Bayerische Staatsbibliothek Cod. hisp. $150.30 \times 21 \mathrm{~cm}$.

Libro del caballero Zifar, Paris, Bibliothèque Nationale, Fonds Esp. $36.40 \times 26$ $\mathrm{cm}$.

Libro del caballero Zifar, Madrid, Biblioteca Nacional 11309. Fifteenth century. $29 \times 21.3 \mathrm{~cm}$. 
The Metz Coronation Sacramentary, Paris, Bibliothèque Nationale, lat. 1141. 869. $26.7 \times 20.5 \mathrm{~cm}$.

Mocedades de Rodrigo, Paris, Bibliothèque Nationale, Fonds Esp. 12. $38.5 \mathrm{x}$ $26.5 \mathrm{~cm}$.

Pericopes of Henry II, Münich, Bayerische Staatsbibliothek Clm. 4452. 1007 or 1012. $42.5 \times 32 \mathrm{~cm}$.

PTOLEMY, Almagest, Vatican Library, Vat. gr. 1594. Ninth century. [Rome Reborn, Plate 111] $31 \times 20.5 \mathrm{~cm}$.

ProlemY, Almagest, Vatican Library, Vat. lat. 2057. Thirteenth century. [Rome Reborn, Plate 112] $30 \times 20.7 \mathrm{~cm}$.

PTOLEMY, Almagest, Vatican Library, Vat. lat. 2056. Late Thirteenth or early Fourteenth century. [Rome Reborn, Plate 113] $33.5 \times 23.5 \mathrm{~cm}$.

PTOLEMY, Almagest, Vatican Library, Vat. lat. 2055. Ca. 1481. [Rome Reborn, Plate 114] $39.8 \times 27.8 \mathrm{~cm}$.

St. John's Bible, St. John's University, Collegeville, Minnesota. 2001-2006. 58.4 x $40 \mathrm{~cm}$.

Urbino Bible, Vatican Library, Urb. lat. 1-2. 2 vols. 1476-1478. [Rome Reborn, Plate 1] $60.3 \times 42.2 \mathrm{~cm}$.

Uta Codex, Münich, Bayerische Staatsbibliothek Clm. 13601. Ca. 1025. 38.2 x $27.4 \mathrm{~cm}$.

Vergilius Vaticanus, Vatican Library, cod. lat. 3225. Early fifth century. $21.9 \mathrm{x}$ $19.6 \mathrm{~cm}$.

Vienna Genesis [Codex Purpureus Vindobonensis], Vienna, Österreische Nationalbibliothek, col. theol. gr. 31 . Sixth century. $33.5 \times 25 \mathrm{~cm}$. 